\title{
The Uyghurs in Xinjiang - The Malaise Grows
}

After September 11th 2001, the Chinese regime strove to include its repression of Uyghur opposition within the international dynamic of the struggle against Islamic terrorist networks.

\section{Rémi Castets}

\section{OpenEdition}

\section{Journals}

Édition électronique

URL : http://journals.openedition.org/chinaperspectives/648

DOI : 10.4000/chinaperspectives.648

ISSN : 1996-4617

\section{Éditeur}

Centre d'étude français sur la Chine contemporaine

\section{Édition imprimée}

Date de publication : 1 octobre 2003

ISSN : 2070-3449

\section{Référence électronique}

Rémi Castets, « The Uyghurs in Xinjiang - The Malaise Grows », China Perspectives [En ligne], 49 september-october 2003, mis en ligne le 17 janvier 2007, consulté le 28 octobre 2019. URL : http:// journals.openedition.org/chinaperspectives/648 ; DOI : 10.4000/chinaperspectives.648

Ce document a été généré automatiquement le 28 octobre 2019

(c) All rights reserved 


\section{The Uyghurs in Xinjiang - The Malaise Grows}

After September 11th 2001, the Chinese regime strove to include its repression of Uyghur opposition within the international dynamic of the struggle against Islamic terrorist networks.

\section{Rémi Castets}

\section{NOTE DE L'ÉDITEUR}

Translated from the French original by Philip Liddell

1 Over the past twenty years, the unrest in Xinjiang has intensified and Uyghur nationalist feeling has strengthened. This study aims to throw light on the causes of the current rise of Uyghur nationalism and the forms it has taken. We shall draw attention to the determining effect of a socio-political context driven by colonial logics in order to explain how the nationalist ideology has been reinforced, with its aim of restoring to the Uyghurs-or more generally to the Turkic-speaking population of Xinjiang-the reins of political power within a truly autonomous or even independent entity. We shall also underline the impact of recent changes within the political context of China and Central Asia ${ }^{1}$.

A turbulent historical and political context

2 Xinjiang (East Turkistan ${ }^{2}$ ), which was annexed by China in the mid-eighteenth century, is mainly populated by Turkic-speaking ${ }^{3}$ Muslims $^{4}$, the majority of whom are Uyghurs ${ }^{5}$ (see Table 1). Despite a long tradition of exchanges with China, these people are linked, primarily by ties of culture and religion, to the Central Asian world. Probably this is one reason why, though they are becoming increasingly integrated with China, they have never very willingly accepted the idea of sharing a common destiny with the Chinese people. However, looking beyond questions of culture, other factors at different times have contributed to weakening Chinese sovereignty over this region. Thus, during the first half of the twentieth century, driven by the local elite in contact with Turkey and 
with the Tatars of Russia, Pan-Turkist reformism ${ }^{6}$ put down the first ideological markers of what were to become Xinjiang's anti-colonial movements ${ }^{7}$. At a time when Chinese power at the centre was weakening and the great powers (such as Britain and Russia) were attempting to exploit the various political factions to build up their influence, two independent republics were founded in Xinjiang. The Turk Islamic Republic of East Turkistan (TIRET) was led by the emirs of Khotan and by anticommunist Pan-Turkists and was centred on the region of Khotan and Kashgar (1933 and 1934) ${ }^{8}$. And then, between 1944 and 1949, the East Turkistan Republic (ETR) was supported by the Soviets and based in the three northern districts of Xinjiang along the frontier with the USSR 9 .

3 From 1949 onwards, the re-emergence of a new and strong centralised power enabled China to reassert sovereignty over the region. The communist regime then introduced a nationalities policy modelled on the Soviet pattern: 55 national minorities (shaoshu minzu), together with the Han, make up the Chinese nation. Ever since, for the first time in China, this policy has guaranteed the recognition of the linguistic and cultural identities of the national minorities, while granting them certain advantages, helping them to integrate within the new system ${ }^{10}$.

4 At the same time, once the opposition of Pan-Turkist separatists and the last of the underground rebels had been eradicated, the province of Xinjiang was transformed, in 1955 , into an autonomous region. But this autonomy was in reality only symbolic, and contrasted sharply with the real political autonomy that many had been hoping for. Indeed, the region's political system remains under the control of the Communist Party, itself dominated by the original Han population of China's interior. The shortcomings of this system built up a powerful sense of frustration, preventing Uyghur society from realising many of its aspirations and from challenging certain policies it had overwhelmingly rejected; of these, undoubtedly the most unpopular was the colonisation of the region.

5 From the 1950s onwards, the communist regime encouraged the settlement of Han population centres in order to secure, control and exploit the region, which is rich in hydrocarbons, mineral resources and virgin agricultural land ${ }^{11}$. Since 1949, the region has seen a massive inflow of Han immigrants mainly directed there by the Xinjiang Production and Construction Corps (XPCC) (Xinjiang shengchan jianche bingtuan). Originally, this organisation had helped former soldiers demobilised after the Civil War to settle down, by providing some advantages to its members. These corps of "peasantsoldiers" sent to the margins of the country to open up new pioneer areas did not survive the Cultural Revolution, except in Xinjiang where they were revitalised during the 1980s in order to pursue demographic colonisation while boosting the manpower needed to provide security for the region. Subsidised up to $80 \%$ by the central government, the XPCCs today control nearly one-third of the local farmed land and produce about a quarter of the provincial industrial output ${ }^{12}$. During the 1950s, the XPCCs had about a hundred thousand members; today their numbers are above 2.4 million, of whom $90 \%$ are Han (that is, one-third of the Han living "officially" in Xinjiang ${ }^{13}$ ). Thanks to the XPCCs, and also to migratory inflows not directly controlled by the state, the Han population has risen from $6.7 \%$ of the region's population in 1949 to about $40 \%$ today, that is, more than seven million out of a total of 18.5 million inhabitants (see Table 1). But colonisation has not stabilised the region-far from it. Its socio-economic repercussions, together with Peking's domineering attitude towards 
the regional political system, have generated a malaise that has lent new vigour in recent years to Uyghur nationalism and separatism.

This phenomenon has been catalysed at the same time by changes in the political context of the region. Indeed, the victory of the Afghan mujaheddin over the Red Army and, with the break-up of the Soviet Union, the independence of the central Asian republics have galvanised Uyghur separatism. Many of the militants have seen in the emergence of national states as homelands for the other large Turkic populations of Central Asia (Kazakhstan, Kirghizstan, Uzbekistan, Turkmenistan ...), the justification of their own aspirations to independence. Moreover, by reason of the cultural and religious ties that the Uyghurs share with the rest of Central Asia, these events have given them hopes of drawing new support from beyond their own borders. This potentiality for destabilisation, the concomitant swell of unrest in Xinjiang and the rise of Islamism ${ }^{14}$ in Central Asia during the 1990s have led Peking to react.

China, torn between the necessity for opening its frontiers to economic inflows and the wish to isolate Uyghur opposition from any exterior support or "subversive" influence, has combined its policy of speeding up the region's economic development with strengthening its security collaboration with its neighbours, pursuing demographic colonisation and stiffening its repression of those political activities that it considers unlawful. But, by failing to take account of either the destabilising impact of colonisation on Uyghur society or the demand for self-government among the local population, these policies could not solve the real problems behind the growth of unrest.

The origins of Uyghur malaise: colonisation and socio-economic stratification

Colonisation and its socio-economic consequences are much disliked by the Uyghurs: they constitute the main grievance among the protest movements. Indeed, colonisation tends, through a complex process, to exclude Xinjiang's national minorities from the benefits of economic advance. In attempting to stabilise the region, the central state has made significant investments ${ }^{15}$ that have contributed to developing the local economy. This region, once among the poorest in China, today, within the provinces of China's "Great West" 16 , now boasts the highest per capita GDP; in these terms it ranks twelfth among all China's provinces ${ }^{17}$. However, these encouraging macro-economic figures hide pronounced inequalities that apply along ethnic lines. To Uyghur eyes, the investments are directed first towards the areas of colonisation ${ }^{18}$, and have benefited the Han colonists most of all. Thus, the per capita GDP in Han areas is far higher than that in areas where the Uyghurs are still in the majority (see Table 2). The low figure for GDP per head in the Tarim Basin, where three-quarters of Xinjiang's Uyghur population is concentrated, makes it likely that a significant number of families have incomes below the Chinese poverty threshold and even further beneath the threshold set by the international organisations ${ }^{19}$.

9 At the same time, these differences in income imposed along ethnic lines underlie unequal access to the educational system-which, in turn, serves to reinforce the economic inequalities. In effect, the inability of the poorest people to finance their children's schooling perpetuates-even more than linguistic handicaps ${ }^{20}$ and a sometimes discriminatory job-recruitment system-socio-professional inequalities condemning much of the Uyghur population to the lowest rungs of society. 


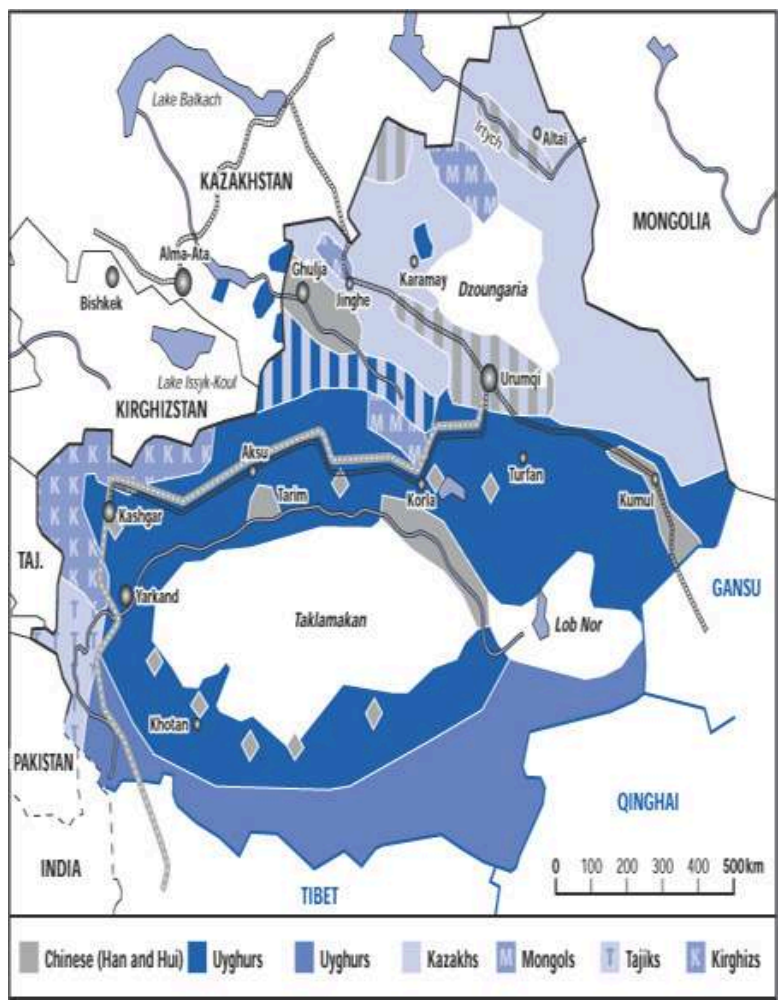

10 Theoretically, the Chinese education system is supposed to make it easier for minorities to climb the social scale, by means of a system of quotas and university scholarships. However the partial withdrawal of the state from financing the education system has led to an increase in schooling costs and falling numbers of scholarships. With the liberalisation of the chinese economy, some financial security is more and more necessary in order to pursue one's studies. The poorest families do not have the means to provide a full education for their children; and they have to restrict their years at school. While Han families, usually urban and better off, can extend their children's education, and send them to the best establishments, the children of the minority communities are unable to complete their secondary education (see Table 3), which means they leave school with fewer qualifications (see Table 4).

11 These differences in educational funding combined with recruitment methods that are often discriminatory in the private sector ${ }^{21}$ tend to perpetuate, over a period of several decades, socio-professional stratification: Uyghurs are penalised in comparison with the Han. The national minorities in Xinjiang are over-represented at the bottom of the socio-professional scale and the Han are over-represented at the top. Thus, while the national minorities represented nearly $54 \%$ of Xinjiang's population in 1990 , they accounted for more than $76 \%$ of its agricultural workforce (as against $69.4 \%$ in 1982 when they were $52.8 \%$ of the total population), less than $41 \%$ of those employed in liberal and technical professions and less than $30 \%$ of managers and administrators ${ }^{22}$.

As the national minorities descend the socio-economic scale in Xinjiang, their living standards become more precarious because China has almost no social security system whatever. According to the 1990 census, the infant mortality rate among the national minorities in Xinjiang was 3.6 times higher than among the Han and their life expectancy was 62.9 years as against 71.4 for the Han. At the same time, unemployment 
among young Uyghurs has led to higher crime rates and drug-taking-though these are culturally alien to this Muslim society. Poverty, and also the inequalities mentioned above, give Uyghurs the sense that they are excluded from economic growth to the benefit of the Han. The status of "second-rate" Chinese citizen contrasts with the promises of wealth and equality made by the regime at the time of Xinjiang's "peaceful liberation", and it has led many Uyghurs to think that they have been fooled by Peking's communist pretensions and that, in reality, they are living under the yoke of a colonial regime.

Elite expectations and nationalism among the Uyghurs of Xinjiang

It is suggested, in the debate over the notion of internal colonialism ${ }^{23}$, that under administrations that are colonial or perceived as such, socio-economic stratification along ethnic lines around the peripheries of some states is likely to encourage an increasing sense of identity and the rise of nationalism. Even though this kind of approach does not explain all the factors and paradigms entering the equation in the birth and the growing influence of nationalism in Xinjiang since the start of the twentieth century, it does help us to see how such inequalities have favoured the strengthening of Uyghur nationalism over the past twenty years. Indeed, going beyond cultural identity, socio-economic and political stratification in Xinjiang has brought many Uyghurs to view themselves as a lower-grade community, separate from the central community (that is to say, the Han) that dominates the economic and political systems. To that extent, it has favoured the emergence of anti-colonial nationalism ${ }^{24}$, fuelled by the distinctive identity of the Uyghurs to legitimise the establishment of real self-government (which would at last serve the interests of the Uyghurs-and not those exclusively of Peking and the Han).

The Uyghur elite, more numerous and driven to compete with the Han, have increasing difficulty in fitting into the system ${ }^{25}$. It is true that the Chinese regime does attempt to co-opt a proportion of the Uyghurs into the administration but, even though noteworthy efforts have been made since the 1950s, it seems that over these last decades they have not been enough to integrate all the new Uyghur elite inside the system. In the 1950s, because of the small number of Uyghurs who had been educated, it was relatively easy for them to find posts on a level with their expectations. Over the past twenty years, with the end of the policy of the "iron rice bowl" (tiefanwan) and the arrival of greater numbers of well-qualified Uyghurs and, in particular, Han in the job market, the integration of some elite Uyghurs has become more problematical. Thus, many young Uyghurs of working-class or middle-class origins reproach the Chinese regime for not providing them with job opportunities commensurate with their training and, instead, for favouring the appointment of Han to management posts ${ }^{26}$.

The small amount of data relating to the ethnic origins of some of the Xinjiang elite appears to support such contentions. For example, in 1990, the national minorities provided only $28.8 \%$ of the total number of managers and administrators in Xinjiang ${ }^{27}$. This state of affairs is also observable within the political system: officials drawn from the national minorities are still under-represented in the Xinjiang Communist Party. They accounted for only $37.3 \%$ of its members in $1997^{28}$. Moreover, bearing in mind that their loyalty towards Peking is considered suspect, they are often held down in posts with little power or posts where they can easily be controlled. Admittedly, the Presidents of the People's Government of the Xinjiang Uyghur Autonomous Region, of each Autonomous Prefecture and of each Autonomous Village are elected on the basis 
of the titular nationality of the autonomous administrative entity. However, as everywhere else in China, the Chinese Communist Party (CCP) is the controlling force behind political institutions. And the most important CCP posts in Xinjiang are held by Han loyal to Peking and not by members of national minorities. For example, it is revealing to note that, ever since 1949, the post of Secretary of the CCP in the Xinjiang Uyghur Autonomous Region has been occupied in an almost systematic way by Han Chinese.

In sum, while a proportion of the Uyghur elite is integrated, even very well integrated, and has been for several generations, a growing number of the new elite find increasing difficulty in fulfilling their expectations and feel resentful of being excluded, even colonised. Shifting this fault line, where the integration of Uyghur elites is concerned, acts as a kind of measuring instrument for Uyghur nationalism. If the indicator moves towards "fewer well-integrated elite", the nationalist opposition is likely to show itself more structured and more vigorous. Today, the fact that poorly integrated elite Uyghurs are more numerous than before explains the rising discontent among young educated people and the strengthening of their political opposition. Yet, the fact that a proportion of them continues to be "well integrated" harms the structure of Uyghur nationalism by preventing for the present the large-scale recruitment of officials likely to organise mass movements.

Reassertion of identity and Islamic revival among the Uyghurs of Xinjiang

Ever since the dark days of the Cultural Revolution, the relative openness that has followed Deng Xiaoping's rise to power has left the way open to a vast movement for revitalising local culture. The 1980s saw a return towards the traditions and the "imagined foundations" of Uyghur identity. This phenomenon in its many forms manifests itself, for example, in the proliferation of books and academic research into Uyghur history and culture. It has also taken the form, as among the Hui, of an Islamic revival ${ }^{29}$. While publications relating to Islam flourished, mosques were renovated and many new ones built. Similarly, religious education developed strongly: Koranic schools were opened, attached to mosques on the one hand or, on the other, as private schools -usually undeclared ${ }^{30}$. This Islamic revival, observed right across China, has nevertheless assumed a distinctive dimension among the Uyghurs. For them it is part of a logic of return (or perceived return) to practices formerly discouraged or repressed, but it is also at the margin part of a more militant logic using Islam as an instrument for distinguishing Uyghur values ${ }^{31}$ from the non-clerical and atheistic values promoted by the Chinese authorities.

Table 1 : Demographic strength of the main Xinjiang nationalities

\begin{tabular}{|c|c|c|c|c|c|}
\hline \multicolumn{2}{|c|}{ 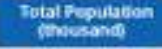 } & Whies & $\operatorname{con}$ & $\begin{array}{l}\text { Caraths } \\
\text { cor }\end{array}$ & thes \\
\hline toce & $4230 \mathrm{D}$ & $3281(75 \%)$ & 291.62751 击 & $443(102 \times 5)$ 틀 & $122(285) 1$ \\
\hline 1964 & 74801 & $4020 \mathrm{~B} 4 \mathrm{4i}$ & $2440(128 \times 1$ & $50157 \times 0 \mathrm{E}$ & $2 \pi 1$ gexal \\
\hline tase & $130 \mathrm{ces}$ & $5950(4 \leq 4 \times)$ & 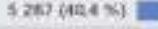 & Sot $(0.9 \times 9)$ & $421(-3 \times 4) 1$ \\
\hline 1900 & 15281 & $3249\{47,4$ SY & $5746075 \times 1$ & $1161(0,4 \times)$ 리 & $588(258) 1$ \\
\hline 2000 & tas 698 & $4525(40 \times 6)[$ & $2250(942 \times 1 \mathrm{E}$ & $13 \sin (9.1 \times)$ & $\operatorname{se}(2.5 \times Y)$ \\
\hline
\end{tabular}

Source: Fenjin de sishi nian: 1949-1989. Xinjiang fenci (The advancing 40 years. 1949-1989. Xinjiang Volume), Zhongguo tongji chubanshe, Urumchi, 1989, p. 332; 2002 Xinjiang tongji nianjian (Xinjiang Statistical Yearbook), Pékin, Zhongguo tongji chubanshe, 2002, pp. 107, 109.

18 The revival of the Uyghurs' Islamic culture and identity has also led, during the 1980s, to the formation of student associations aiming to promote the rights and culture of 
the Uyghurs: the Tengritakh Association (Tianshan), the Youth Association of East Turkistan, the Students' Cultural and Scientific Association ${ }^{32}$... Some of these student associations, which reflect the growing strength of the democratic student movement in China and challenge "Great Han chauvinism", seem quickly to have adopted a militant style. This is conveyed in a report reflecting CCP anxiety:

In the thirty years between 1949 and 1979, almost no demonstration was held by the Xinjiang minority students in Xinjiang, but after 1980, student demonstrations have broke out one after another. This is a new phenomena. Uyghur students from seven universities and colleges including Xinjiang University in Urumqi demonstrated on December $12^{\text {th }} 1985$. They were openly against the Central Government's decision. [. . . ] Some of the students from Xinjiang University got together and organized this well planned and well organized political incident for which the Xinjiang University became the headquarter. Before and after that incident, some pro-separatism posters and flyers with contents such as: "Chinese out of Xinjiang", "Independence for Xinjiang", "Cut off the railroad from China proper to Xinjiang" were discovered in Urumqi and other districts. In June 1986, another demonstration was organized by a student association in Xinjiang University. [. . .] Using the "support for the minority education" as a cover, they attacked Central Communist Party's minority autonomy policy, damaged the good relationship among the nationalities. They used slogans such as "No big Chinese Nationalism", "No Chinese population transfer to Xinjiang", and created a very bad influence in the society. ${ }^{33}$

Outside the campuses, the revival of the meshrep ${ }^{34}$ expresses the wish to revitalise Uyghur culture and identity. At the start of the 1990s, young Uyghurs of the region of Ghulja (Yining) launched a movement to re-invigorate these gatherings which have spread rapidly. However, the movement has also taken, according to the Chinese authorities, a "counter-revolutionary" turn. Fearing that it might become a focus for protest and "local nationalism" (difang minzuzhuyi), the regional government banned the meshrep in 1995; and the people who had launched the movement were imprisoned ${ }^{35}$.

The rise and fall of two clandestine political movements of some stature

21 This aspiration to greater militancy ${ }^{36}$ has also taken the form of clandestine political movements ${ }^{37}$ that, in Xinjiang and in the Diaspora ${ }^{38}$, are founded on Uyghur nationalism tinged with Pan-Turkism ${ }^{39}$. Admittedly, these movements are not "mass movements"-and even less so in the present climate of repression. Uyghur militancy is driven mostly by a fringe group of young students and intellectuals, purged regularly by Chinese repression. Up until the 1990s, two successive clandestine groups in the tradition of the pre-1949 oppositional currents, both quite durable, dominated the underground political scene. Of these two nationalist Pan-Turkist parties, one, socialist and secular, relied on Soviet aid, and the other came from the anti-communist and Islamic tradition centred on the south of Xinjiang. Both could call upon a base of militancy that was relatively wide compared with present-day groupings (see below). At the same time they were counting on significant underground mobilisation to prepare for a general uprising in Xinjiang.

22 After 1949, the first big organised clandestine party was formed under the name of the Eastern Turkistan People's Party (ETPP) (Sharki Turkistan Halk Partisi). Mainly drawing in Uyghurs but also Kazakhs, it was founded in secret, according to the Chinese authorities, in February 1968; but, according to the militants who have now taken 
refuge abroad, some of its cells had already been active for several years beforehand ${ }^{40}$. This was a separatist Pan-Turkist party with Marxist allegiances. Well-structured and hierarchic, it swiftly recruited former officials of the East Turkistan Republic as well as young people from Turkic-speaking minorities. According to the East Turkistan National Centre, this party numbered more than 60,000 members and 178 branches in Xinjiang $^{41}$. These figures are hard to verify. However, the ETPP is probably the largest secret organisation ever created since the liberation of Xinjiang. The rise to power of this underground party seems to have been favoured mainly by the excesses of the Cultural Revolution and by the deterioration of Sino-Soviet relations. Indeed, the USSR did give help to the ETPP. As is confirmed by Chinese sources and the testimony of some of its former militants, the KGB developed its links with this party mostly through its agents active in Kazakhstan and seems to have provided it with logistical support on several occasions:

The ETPP's Central Committee and subcommittee drafted articles such as "The Destiny of the Uyghurs", "Eastern Turkestan People's Party's Constitution" and "Eastern Turkestan People's Party's General Principles". [. . .] they all claim [. . .] "Seize the power with the help of the Soviet Union and establish an independent Eastern Turkestan Republic" [. . .]. Some of them even held the banner of Marxism and Leninism and proposed: "We want to establishing an independent country according to the Marxist principle of self-determination of different peoples". [. . .] On a dozen occasions, the "ETPP"'s Ili Committee, Urumqi Branch, and Altay Bureau also sent their delegations to Soviet Union and Mongolia Republic to beg for arms and the use of radio stations for their riots and ask for military advisors. The Soviet Spy agency sent a group of fourteen people with spies carrying radio transmitters, weapons and funds for their activities. These groups arrived in Xinjiang and established communication with the "ETPP" nine times. ${ }^{42}$

Table 2 : Distribution of wealth in the main sub-regional administrative units in Xinjiang

\begin{tabular}{|c|c|c|c|c|c|}
\hline 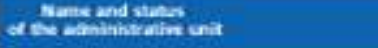 & & 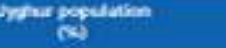 & & Mis portatom & Nor Gite cot \\
\hline Kromy fergy, sith & 13,63 & $=$ & 727,036 & 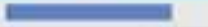 & 43926 E \\
\hline unselfoup & $128 \times$ & $\mathbf{m}$ & 2328 & 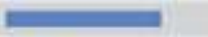 & istes $=$ \\
\hline 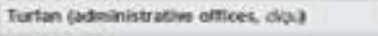 & e9:5: & ב & $235 \%$ & - & $12895=$ \\
\hline shtezi fazent & $12 \times$ & & $\operatorname{sen} x$ & & จ \\
\hline 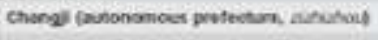 & $4 \%$ & 1 & $748 \%$ & $=$ & $890=$ \\
\hline 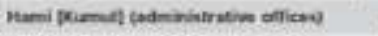 & $154 \times$ & $=$ & $\operatorname{eap} 7=$ & $=$ & $7351=$ \\
\hline 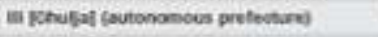 & $159 \%$ & $=$ & 4098 & 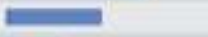 & $5344=$ \\
\hline Aker isaminht min offisen & reas & $=$ & 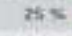 & 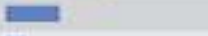 & 6900 \\
\hline 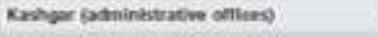 & $802 \times$ & $=$ & 21\% & : & 24111 \\
\hline 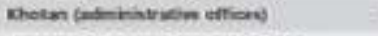 & seis & $=$ & 35 & I & $\cos 1$ \\
\hline Anrrape in the province of Xopiang & $45 \mathrm{x}$ & 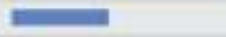 & 3918 & 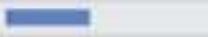 & $\operatorname{sen} 3$ \\
\hline Anorap in chans & & & & & ses $=$ \\
\hline
\end{tabular}

Source: 2002 Xinjiang tongji nianjian, op. cit., pp. 106, 110-115, 713, 715; 2002 Zhongguo tongji nianjian, op. cit., p. 51.

The ETPP focused its activity on mobilising Turkic-speaking populations and officials in Xinjiang with the aim of preparing a mass insurrection against Peking. At the same time, it took up guerrilla activities (sabotage, skirmishes with the police and the Chinese army...) and was behind various attempts at insurrection during the 1960s and the 1970s. Still quite active during the 1970s, it was gradually weakened by the arrest of its leaders, by the gradual falling away of Soviet support as the tension between Moscow and Peking relaxed, and then by the decline of the communist ideology. 
Nevertheless, while the ETPP was in decline, a new party of anti-Marxist opposition was developing in southern Xinjiang.

As the Soviet Union lost its appeal among anti-colonialist Muslims to the benefit of revolutionary Islam, and as the revival of Islamism was gathering pace in Xinjiang, the Islamic Pan-Turkic trend centred on the south of Xinjiang was given renewed vigour by new young leaders. It was re-organised around the East Turkistan Islamic Party (ETIP) (Sharki Turkistan Islam Partisi). This Pan-Turkic nationalist movement also aimed at renewing Islam among the Uyghurs and developed from networks of mosques in southern Xinjiang during the 1980s. According to official sources, it apparently generated offshoots in numerous cities in the Tarim Basin, indeed as far as Ghulja (Yining), Turfan and Urumqi ${ }^{43}$. Probably also inspired by the Afghans' success against the Soviets, it really came into prominence in April 1990 at the time of the Baren insurrection (near Kashgar). The rising took the form of a jihad recalling that which led to the creation of the Turk Islamic Republic of East Turkistan (1933-1934) ${ }^{44}$.

The insurrection, which lasted for several days, caused several dozen deaths on the insurgents' side and forced the Chinese army to deploy significant forces in the region to put down the rebellion. The Chinese authorities view the ETIP as part of the Jihadist current on the other side of the Pamirs; and they consider that it gave birth to more "radical" groupings such as the Party of Allah and the Islamic Movement of East Turkistan. Because of the little information available about this organisation, such links are difficult to check and to determine as true or false. However, the slogans proclaimed during the insurrection suggest that the ETIP at this time was more a renovated form of the Islamic Pan-Turkism historically established in the south of Xinjiang than a pure reincarnation of radical Islam:

$27 \mathrm{He}$ [Yusuf Zeydin, leader of the local branch of the ETIP] and his followers openly shouted: "Down with the socialism!", "In the past Marxism suppressed religion, and now it is religion's turn to suppress Marxism", "Unite all the Turk peoples, long live the great Eastern Turkistan!", “Take Barin, establish Eastern Turkistan”. ${ }^{45}$

The subsequent repression prevented the party from being reconstituted on such wide foundations, despite attempts at this of some of its members in the early 1990 s.

The 1990s: the turn towards repression

29 Whereas the 1980s are perceived by many Uyghurs as a period of reduced tension, even of an improvement in the relations between Uyghur society and the Chinese state, the 1990s saw the emergence of a repressive climate that engendered powerful frustrations and resentment. The 1990s increase in repression is generally linked with exacerbated Party anxieties on several levels.

30 Nationally, the conservative wing of the CCP considered that the worst was avoided after the Tiananmen events in 1989, whereas similar events took place in consequence on campuses in Xinjiang (see above). It considers that an authoritarian crackdown is essential to ensure the survival of the regime. At the same time, at the start of the 1990s, the Chinese regime feared that the accession to independence of the Central Asian Republics, and also the spread of radical Islam in the region (see below), would seriously destabilise Xinjiang if nothing was done. On the one hand, the accession to independence of other large Turkic populations of Central Asia was likely to legitimise and strengthen Uyghur separatism. On the other, the cultural links that bind the Uyghurs together with the peoples of the new Republics, and also with the Uyghur 
Diaspora in these countries ${ }^{46}$, allowed Peking to fear that solidarity would build up between the Uyghur separatists and these states (or certain organisations present on their soil). Firstly, some of them (Kazakhstan and Kirghizstan in particular) have effectively offered asylum to the new refugees, and even recognised organisations of the local Diaspora defending the independence of East Turkistan. Peking then applied itself to cutting off the militants active in Xinjiang from these potential supports outside. By playing on the prospects for settling frontier disputes and for economic cooperation, and by promoting co-operation in the struggle against separatism and Islamism in Central Asia through the Shanghai Co-operation Organisation (SCO) ${ }^{47}$, China persuaded the Central Asian republics to ban the Uyghur organisations present on their territories, and even today to extradite some militants who have recently taken refuge there ${ }^{48}$.

On the domestic front, the Chinese regime confronted by the rise of Uyghur nationalism and by Islamic anti-governmental subversion has progressively tightened its control over society and the spaces for expressing identity and religion ${ }^{49}$ to prevent the start of dynamics that might have made the situation uncontrollable. At the same time as relations between the Chinese state and Uyghur society were becoming strained and disturbances, sometimes violent, were on the rise (the Baren insurrection in 1990, the disturbances of the summer and autumn of 1993 over the whole province, and the riots of July 7th 1995 in Khotan), the Chinese regime's grip was progressively tightened.

Table 3 : National minorities' share in Xinjiang's total school population in 2000

\begin{tabular}{|l|l|l|}
\hline Primary School & $68,0 \%$ & \\
Junior Secondary School & $65,0 \%$ & \\
Senior Secondary School & $45,9 \%$ & \\
\hline University & $43,2 \%$ & \\
\hline
\end{tabular}

Source: 2002 Xinjiang tongji nianjian, op. cit., pp. 612-613.

The turning point really came in 1996-1997, following the launch in April 1996 of the great national campaign against crime "Strike hard". This campaign began shortly after a special meeting in March 1996 on maintaining stability in Xinjiang, and so there it assumed a special dimension, being targeted at separatism and illegal religious activities. The Permanent Committee of the Politburo of the CCP then issued an exhaustive list of strict directives aimed at tightening control over Xinjiang and eradicating potentially subversive activities ${ }^{50}$. As part of the same campaign, a succession of strong-arm police operations was mounted (the special 100-day crackdown from January to March 1999, the "General Campaign against Terrorism" from April to June 1999, the new campaign "Strike hard" from April 2001 onwards, the drive against separatism in October 2001...). This intense campaign of repression led to thousands of arrests and also to constant human rights violations and the improper use of the death penalty ${ }^{51}$. By fencing off, even closing down, the last spaces for the expression of identity or religion ${ }^{52}$, these restrictions put relations between Uyghur society and the Chinese regime under considerable strain. They gave the impression that the real target of the Chinese regime's attacks was not so much separatism or even Islamism but Uyghur identity itself ${ }^{53}$.

More disturbances and more radicalisation during the 1990s 

competition from ever-increasing numbers of Han placed the social climate under strain. Local politicians, in thrall to Peking, are unable to challenge policies imposed from the centre and often very strongly disliked (nuclear tests on the Lop Nor site, the restriction of religious freedoms, the enforcement of birth control while colonists are flooding in...); this fact has provoked numerous protest movements. Faced with a strained social and political climate, the local authorities (who cannot challenge the policies dictated by Peking) have often reacted with brutality. They have sometimes helped to give an insurrectional twist to protest movements that, originally, were merely directed against unpopular measures ${ }^{54}$. While the disturbances became more frequent ${ }^{55}$ in response to excessive Chinese repression, throughout the 1990s new groupings appeared in Xinjiang and the Diaspora. In the Diaspora, most organisations began to federate around the rejection of violent action while lobbying for the Uyghurs' basic rights to be protected ${ }^{56}$; by contrast, in Xinjiang, groups with a sometimes reduced life expectancy, but adopting more radical modes of action, appeared. They protected themselves by keeping their memberships small, or withdrew from China (to Central Asia, Afghanistan or Turkey). barracks or military bases), and even graduated to acts of terrorism (assassinations of Han officials or Uyghur collaborators, and bomb attacks). The increasing frequency of acts of violence and terrorism in Xinjiang during the 1990s does not mean that all the Uyghur political movements support these modes of action. But, just recently, the Chinese authorities have generally harped on about the frequency of acts of violence to give the Uyghur opposition the image of a primarily terrorist force.

Only a short while ago, the Chinese government was opting to hush up the news of these disturbances. However, following the events of September 11th 2001, it decided to put out information about the more violent acts and the terrorist attacks carried out during this period. It attributed some of them to armed groups who, to date, seem mostly to have disappeared or become dormant ${ }^{58}$. The Shock Brigade of the Islamic Reformist Party are held responsible for the attack that, on the Chinese New Year in February 1992, killed three people in a bus at Urumqi ${ }^{59}$. The East Turkistan Democratic Islamic Party is held to have carried out the bomb attacks in the south of Xinjiang that killed four victims between June and September $1993^{60}$. The most memorable crime, that of February 25th 1997 in Urumqi (on the day of Deng Xiaoping's funeral), was attributed to the East Turkistan National Unity Alliance. Four bombs had been planted on different bus routes. The resulting explosions killed nine and wounded 74. On the other hand, the Chinese regime did not mention in its report the crime committed during the annual meeting of the National People's Congress on March 7th 1997: the bomb went off in a bus in Peking's Xidan district (30 injured and two dead). Responsibility for this attack, the first to affect Peking since 1949, was claimed by the Organisation for East Turkistan Freedom (based in Turkey), but the Chinese government denied that any Uyghurs were involved in this attack.

The spread of radical Islam in Xinjiang

36

At the same time, connections have apparently been made between some Uyghur militants and Islamic movements. This phenomenon seems to be linked to several factors. On the one hand, the socio-political model promoted by these movements may have seemed a preferable alternative to the Chinese model perceived as colonial and 
culturally invasive. The desire to establish a political and social order that would put Uyghur Muslims at the centre of the system is very strong. Some Uyghur militants were probably also influenced by the hope that by imposing a strict Islamic framework they might at the same time find a solution to the present social problems. On the other hand, bearing in mind the cessation of support (active or passive) from the USSR and later of the Central Asian republics and taking account also of the indifference of the West ${ }^{61}$, the vital necessity of finding foreign support over which Chinese diplomacy had no hold also played an important role. Some Uyghur movements saw in the Islamic card a means of playing on the solidarity existing between Muslims within the Umma to attempt to win political support, fallback bases, even training facilities and funds to further the struggle against Chinese power in Xinjiang.

The first links seem to have been made during the 1980s. During this period, many foreigners (traders, preachers ${ }^{62} \ldots$..) profited from the relative relaxation of chinese control to proselytise their causes in China itself ${ }^{63}$. At the same time, with the opening of frontiers and the loosening of restrictions governing the Mecca pilgrimage, Uyghurs travelling abroad came into contact with proselytising movements working in Pakistan, Central Asia or in some Arab countries. Links were created in these cases too. At the same time also, as the restrictions on religious education in Xinjiang were being strengthened, many young Uyghurs went abroad. Through connections established during the 1980s or through family links on the spot, these young people-and also Uyghurs in the Diaspora-took religious courses in the Koranic schools sometimes attached to Islamist movements.

Thus, in Kazakhstan it seems that some Uyghurs joined the Islamic Renaissance Party ${ }^{64}$. In Uzbekistan and in Kirghizstan some of them joined the Islamic Movement of Uzbekistan (IMU) or else Hizb-ut Tahrir (HT) ${ }^{65}$. The other favoured place for recruitment was Pakistan. Chinese researchers suggest that about ten thousand Uyghurs went to Pakistan to receive a religious education ${ }^{66}$. This figure is hard to verify. Nevertheless, some of them did indeed follow programmes in fundamentalist Koranic schools in Pakistan, and were even in contact with various local Islamist movements (Jamaat-e Islami ${ }^{67}$, Jamaat al-Tabligh ${ }^{68} . .$. ). Through these connections, some Uyghurs took part in military operations. It seems that the Hizb ul-Mujahidin ${ }^{69}$ and the Salafist Jihadist ${ }^{70}$ movement Lashkar-e Taiba in particular ${ }^{71}$ enrolled a handful of Uyghurs in the Kashmir conflict ${ }^{72}$. However, most of the Uyghurs involved in the Jihad were in Afghanistan (mainly in the ranks of the Hizb-e Islami, the Taliban and later in the ranks of the IMU). Quoting official Russian sources and Chinese experts, the Chinese press has published figures ranging from over 200 Uyghurs in the "bin Laden camps" to more than a thousand having received some military training in Afghanistan ${ }^{73}$. Again, the figures are difficult to check. However, after the fall of the Taliban, the new Afghan government claims it has only a score of Chinese prisoners (who it has promised to hand over to the Chinese authorities). So one may presume that the Uyghurs amount only to a negligible proportion of the foreign supporters fighting alongside local radical movements.

The Islamist faction in Xinjiang: a marginal threat but useful to the Chinese regime

39 During the 1990s, some of these young Uyghurs formed in their turn a small number of Islamist (or Islamic nationalist) groups which, according to Peking, have links with Salafist Jihadist networks based in the region. Because we have little reliable information about these ultra-clandestine organisations, it is very difficult to be 
specific about their ideology. For the most part, they begin with a nucleus of Uyghurs who have often received Islamic training abroad and are sometimes trained in combat and the use of explosives; around them are grouped the militants they themselves have recruited locally. However, the fact that they do not recruit from the Hui and that their discourse lays greater emphasis on liberating East Turkistan than on creating an Islamic state (or on returning to a purified form of Islam) suggests that their agenda is still mainly nationalist ${ }^{74}$.

Without having carried out a massive recruitment, these groups have concentrated on enrolling young people from the urban working class, mainly from southern Xinjiang. Admittedly, the substratum of urban youth, disconnected with Islam in its traditional Sufi form ${ }^{75}$, provides a reservoir of people that could feed the development of these groups. However, although one may recently observe the growing power of the neofundamentalist Hizb ut-Tahrir group ${ }^{76}$, the Islamist groups in Xinjiang have lost much of their membership and have been officially dismantled by the Chinese police. In reality, Chinese security focused its attention firstly on the East Turkistan Islamic Party of Allah (whose name recalls Hezbollah). Founded in 1993 according to some sources and in 1997 according to others ${ }^{77}$, the membership of this organisation campaigning for the creation of an Islamic state numbered from one hundred to fifteen hundred. According to the Chinese authorities, its members attacked individuals associated with the Chinese government. A wave of arrests at the end of the 1990s seems to have uncovered preparations for bombing attacks. In the end, according to the Chinese press, the Party of Allah was dismantled a few years ago.

Table 4 : Differences in qualifications between Han and non-Han labour in Xinjiang in 1990

\begin{tabular}{|c|c|c|c|c|}
\hline & \multicolumn{2}{|c|}{ Man } & \multicolumn{2}{|c|}{ Women } \\
\hline & Han & Minorily Kationalities & Han & Minorily Notionalities \\
\hline Higher Level & $7,03 \%$ 줄 & $3,25 \%$ & $4,42 \% 1$ & $1,53 \% 1$ \\
\hline Sphior Secundary & $24.94 \%$ & $1276 *$ 제 & $26.46 \%$ & $11,05 \%$ \\
\hline Junior Secundary & $4825 \%$ & $25,63 \% E$ & $41.19 \%$ & $1983 \%$ \\
\hline Primary & $16.51 \%=$ & $4296 \%$ & $18.86 \%$ & $4827 \%$ \\
\hline Uliterate & $3.28 \% 1$ & $15.39 *$ 메 & $9,06 \%$ & $1938 \%$ \\
\hline
\end{tabular}

Source: Compilation based on data from the fourth census carried out in 1990 (Emily Hannum \& Yu Xie, op. cit., p. 329).

41 Yet, after the events of September 11th 2001, the marginal existence of this kind of group was used by the Chinese regime to attempt to include the wholesale repression of the Uyghur opposition within the international dynamic of the struggle against Islamist terrorist networks ${ }^{78}$. While the Chinese Foreign Affairs Minister declared in November 2001 at the UN that "the terrorist forces of East Turkistan are trained, equipped and financed by international terrorist organisations", in January 2002 the State Council published an ambiguous report laying stress on the supposed links between al-Qaeda and the Uyghur opposition grouped under the falsely unifying label of Dongtu ${ }^{79}$. In fact, there is no structure that controls all the Uyghur movements in Xinjiang and abroad; and the vast majority of them have no connection, either ideological or organisational, with radical Islam. Yet, by stressing the supposed links of the Party of Allah and the East Turkistan Islamic Movement (ETIM) with al-Qaeda, this report tends to lump together disparate elements of this kind. According to the thesis proposed by the State Council, members of these groups received training in Afghanistan. The leaders of the ETIM (a group that until then was almost unknown) are 
alleged to have met bin Laden at the start of 1999 and in February 2001; and he is alleged to have agreed to provide them with "fabulous sums" 80 . It is possible that these movements, and particularly the ETIM, might have had contacts with the bin Laden network and more probably with the Islamic Movement of Uzbekistan ${ }^{81}$. But the Chinese declarations that attempt to show particularly close relationships fly in the face of bin Laden's silence on East Turkistan.

For his part, the leader of the ETIM, Hasan Mahsum, assured Radio Free Asia on January 22nd 2002 that his ultimate aim was the liberation of Xinjiang; and he denied any organic link with al-Qaeda. Even so, the Chinese lobbying did bear fruit. It enabled China to persuade the US government, at the end of August 2002, and then the UN Security Council to include on the list of groupings linked to al-Qaeda the East Turkistan Islamic Movement; it was given an extended description under a triple name: the East Turkistan Islamic Movement, the East Turkistan Islamic Party of Allah and the East Turkistan Islamic Party ${ }^{82}$.

The Chinese regime and the Uyghur dilemma

The consequences of the policies pursued by the Chinese regime reveal the political impasse it has run into by attacking the expressions of Uyghur malaise without attacking its real causes. Mao Zedong, going back on his promises, quickly opted for repression to put an end to demands for self-government, which had been made as early as the 1950s. The Chinese regime then outlawed any kind of protest against the policies imposed on Xinjiang; it also closed up most of the spaces in which the culture and the religious convictions of the Uyghurs could be expressed. In this way it fed frustrations that were also exacerbated by colonisation and the socio-economic stratification that it led to. When, to reduce tension, the regime partially re-opened these spaces, the re-opening simply allowed the power of Uyghur nationalism to grow. And since Peking closed the spaces and reverted to repression, all hopes of selfgovernment, even of dialogue with the Chinese authorities, have flown out of the window. Now that relations have completely broken down, acts of violence have replaced peaceful demonstrations as the expression of the Uyghur malaise. Isolated as they have been by skilful Chinese diplomacy, what remains of the Uyghur opposition in Xinjiang is now open to all kinds of extremism.

\section{NOTES}

1. This study is based mainly on data gathered by the author since the end of the $1990 \mathrm{~s}$ in Xinjiang and within the Uyghur Diaspora.

2. Sharki Turkistan in Uyghur.

3. Historically, these communities shared the various ecological niches in the area. The oases to the south of the Tianshan mountains, that is to say the oases of the Tarim, Turfan and Kumul (Hami) Basins are traditionally populated by sedentary Uyghurs. The Tianshan chain and the steppes to the north are home to the Kazakh and Kirghiz nomads. To these Turkic-speaking populations are added the nomadic Mongols to the 
north and east, a Tajik community in the Pamirs and a few Uzbek and Tatar traders in the large oases. Following the conquest of the region by the Qing, Han, Manchurian population demobilised or sent there to ensure control of the north of the province, and Chinese Muslims (Hui) came to settle.

4. These Turkic-speaking populations have in common to be Sunni muslims of the Hanafi rite and to practise an Islam influenced by Sufism. Only the Tajiks of the Chinese Pamirs depart from this rule. They are Iranian-speaking, and are part of the Ismaelian branch of Shiism.

5. Until the twentieth century, these populations, fragmented by differences of identity and by political and religious rivalries between oases, referred to their geographic origin (their oasis of origin) to identify themselves. The term Uyghur refers to the Turkic people who, in the Middle Ages, developed a brilliant civilisation in the east of Xinjiang. This ethnonym, having disappeared since Islamisation, was revived by Russian ethnologists; it was brought back into service during the 1930s by Soviet advisors of Sheng Shicai to designate the Turkic-speaking sedentary Muslim communities speaking the Turki dialect of the Xinjiang oases. See Dru Gladney, "The Ethnogenesis of the Uighur", Central Asian Survey, Vol. 9, No. 1, 1990, pp. 1-28; Abdurahman Abdullah, Tashkentchilair (Those who have studied in Tashkent), Xinjiang Renmin chubanshe, 2002.

6. Pan-Turkism, which was partly confused with Jadidism in Central Asia, developed in the 1880s among the Tatars of Russia. This reform movement aimed to restore political influence to the Muslim Turkish peoples and to awaken their national consciousness by modernising them (educational reforms, theological reforms...) Though it cannot be on the scale of the Turkish world as a whole, Pan-Turkism, closely mingled with Uyghur nationalism, helps to unite the various Turkic-speaking populations of East Turkistan behind the same political project.

7. Masami Hamada, "La transmission du mouvement nationaliste au Turkestan oriental (Xinjiang)”, Central Asian Survey, Vol. 9, No. 1, 1990, pp. 29-48; Justin Rudelson, Oasis Identities: Uyghur Nationalism Along China's Silk Road, New York, Columbia University Press, 1997, pp. 55-57.

8. Andrew D. Forbes, Warlords and Muslims in Chinese Central Asia, A Political History of Republican Xinjiang 1911-1949, Cambridge, Cambridge University Press, 1986, pp. 63-121. 9. Linda Benson, The Ili Rebellion: The Moslem Challenge to Chinese Authority in Xinjiang, 1944-1949, New York, Armonk, Sharpe, 1990; David Wang, Under the Soviet Shadow: The Yining Incident; Ethnic Conflicts and International Rivalry in Xinjiang, 1944-1949, Hong Kong, Chinese University Press, 1999.

10. Barry Sautman, "Preferential Policies for Ethnic Minorities in China: the Case of Xinjiang", Nationalism and Ethnic Minorities, Vol. 4, No. 1/2, spring/summer 1998, pp. 86-113.

11. This colonisation policy, for example, has just been openly encouraged anew by the Permanent Committee of the Politburo of the CCP on March 19th 1996: its confidential session was devoted to maintaining stability in Xinjiang ("Guanyu weihu Xinjiang wending de huiyi jiyao, zhongyang zhengzhiju weiyuanhui” An English version of this text has been published by Human Rights Watch).

12. James D. Seymour, "Xinjiang's Production and Construction Corps and the Sinification of Eastern Turkestan", Inner Asia, Vol. 2, No. 2, 2000, pp. 171-94; Nicolas Becquelin, "Chinese hold on Xinjiang: Strengths and Limits", in François Godement ed., La Chine et son Occident. China and its Western Frontier, Les Cahiers de l'Asie, IFRI, Paris, 
2002, pp. 62-66; Xinjiang shengchan jianshe bingtuan tongji nianjian, (Statistical Yearbook of the Production and Construction Corps in Xinjiang), Peking, Zhongguo tongji chubanshe, 1999.

13. It is hard to calculate the real number of Han living in Xinjiang because the Chinese authorities, in their statistics, only declare communities under the jurisdiction of regional authorities and not those under the jurisdiction of the central authorities. 14. By Islamism, we shall understand any movement led by intellectuals benefiting from a modern education whose aim is "to build, starting with the power of the state, a global political system which would manage all aspects of the society and the economy, founding its authority only on Islam and rejecting any political pluralism", (Olivier Roy, Généalogie de l'islamisme, Hachette, Paris, 2002, p. 10).

15. Bearing in mind the structural deficit of the autonomous region's finances (about $50 \%$ of the regional budget at the end of the 1990s), Xinjiang is mainly dependant on funding from central government (see Nicolas Becquelin, "Xinjiang in the nineties", China Journal, No. 44, July 2000, pp. 71-74).

16. In January 2000, Peking launched the campaign it called "Opening up the Great West" (Xibu dakaifa) in order to reduce the development gap between the East and the West of China. It aims in particular to encourage investment in the whole area made up of the Xinjiang Uyghur Autonomous Region, the Autonomous Regions of Tibet, of Ningxia, of Guangxi, of Inner Mongolia, the provinces of Qinghai, Gansu, Shaanxi, Sichuan, Yunnan, Guizhou and the municipality of Chongqing. Although the effectiveness of the proposed measures is doubtful, the Xinjiang authorities refer frequently to them to assure the autochthonous populations that they have not been abandoned and that all measures are being taken to improve their living conditions. On the campaign and what is at stake, see David S. G. Goodman, "The politics of the West: equality, nation-building and colonisation", in La Chine et son Occident. China and its Western Frontier, IFRI, Les Cahiers d'Asie, Paris, 2001, pp. 23-55.

17. 2002 Zhongguo tongji nianjian (Statistical Yearbook of China), Peking, Zhongguo tongji chubanshe, 2002, p. 51.

18. The main pioneer areas were opened up along the Hami-Turfan-Urumqi-ChangjiShihezi line, and along a line pushing out westwards (Yanji-Korla-Luntai-Aksu...). Extending the transport infrastructures mainly favoured colonisation by making zones that were formerly remote more accessible to the colonists. In the 1950s, only Kumul (Hami) was linked to the rest of the Chinese railway network. Urumqi was linked up in 1960. The Turfan-Korla section was completed in 1984, connecting Urumqi to the Kazakh frontier was achieved in the early 1990s and the Korla-Aksu-Kashgar section in 1999. The cross-desert road linking Khotan to Korla was finished in 1995. Thus, since the north of the Tarim Basin was given its rail link to the Chinese network and since Khotan was linked by road to the north of the Tarim Basin, the historical centres of Uyghur population, once isolated, have been receiving a steady influx of colonists. 19. The threshold set by the international organisations is about a dollar per day (that is, about 3,000 yuan per year).

20. In Xinjiang, bearing in mind the omnipresence of putonghua in the administration and the economy, it is essential to master it in order to rise to posts of responsibility. Young Uyghur pupils have a choice between attending "Uyghur classes" where teaching is conducted mainly in Uyghur and "Chinese classes" where teaching is conducted in Mandarin (Chinese). The Uyghur elite (often mastering Mandarin by themselves) frequently send their children to the Chinese classes to ensure for them 
better chances of professional success. However, bearing in mind the risks of losing one's own culture that this choice incurs for some people, bearing in mind the fairly strict compartmentalisation of Han and Uyghur housing, and also because in the remote rural Uyghur areas these Chinese classes are not available, most Uyghur families send their children to the "Uyghur classes" near where they live. Thus, many young people, despite the existence of Chinese lessons and classes taught in Chinese in the "Uyghur classes", do not master Chinese by the time they leave.

21. The continuous influx of the Han produces on the labour market significant tensions that are aggravated by the fact that the economy is dominated by the Han. Since Han people prefer to be surrounded by Han people, the jobs that they create go to them and not to the Uyghurs. This "preferential job recruitment" is mainly observable in the private sector where there is no encouragement for employers to recruit from the national minorities. Many Uyghurs speak resentfully of this kind of discrimination in the labour market and complain that, with equal or superior skills, they cannot compete with the Han or the Hui (Interviews, Xinjiang, 1999-2002).

22. Emily Hannum and Yu Xie, "Ethnic stratification in Northwest China: occupational differences between Han Chinese and national minorities in Xinjiang, 1982-1990", Demography, Vol. 35, No. 3, 1998, p. 328.

23. See Michael Hechter, Internal Colonialism: The Celtic Fringe in British National Development, 1536-1966, London, Routledge and Kegan Paul, 1975. Whether Xinjiang fulfils the half-dozen criteria that qualify a territory as an interior colony is the subject of much debate. However, in our opinion, whether the peripheral community considers itself to be colonised is more important than validating these criteria, when it comes to understanding how these situations of stratification (perceived or real) can lead to ethnic nationalism.

24. Interviews, 1999-2002. See for example, East Turkistan Information Center (ETIC), "Sherqiy Turkistanda Bashbalasi Hitay Koçmenliri" (The Chinese Migrants in East Turkistan), www.uygur.org.

25. Interviews, Xinjiang, 1999-2002.

26. Ibid.

27. Cf note 22 .

28. Colin Mackerras, "Xinjiang and the causes of separatism", Central Asian Survey, Vol. 20, No. 3, 2001, p. 290.

29. See Elizabeth Allès, Leïla Chérif-Chebbi \& Constance-Hélène Halfon, "L'islam chinois, unité et fragmentation”, Archives de sciences sociales des religions, $\mathrm{n}^{\circ} 115,2001$, pp. 15-47.

30. On religious education in China, see Elisabeth Allès, "Muslim Religious Education in China", China Perspectives, No. 45, January-February 2003, pp. 21-29.

31. As Pierre Bourdieu has underlined in his analysis of the relationship between the habitus and class conflicts, the habitus is governed by relational influences. Above all, it is public, in that it is meant to carry meaning in other people's eyes. In this regard, the study of the evolution of the Uyghur habitus gives us extensive information on the nature of the relations between the Uyghurs and the Chinese centre.

32. Artoush Kumul, "Le séparatisme ouïghour au XXe siècle", CEMOTI, $\mathrm{n}^{\circ} 25$, JanuaryJune 1998, p. 88.

33. Zhang Yumo, "The Anti-Separatism Struggle and its Historical Lessons since the Liberation of Xinjiang" in Yang Faren et al., Fanyisilanzhuyi, fantujuezhuyi yanjiu (Study on Pan-Islamism and Pan-Turkism), 1994, a document translated and published in 
English on the web site of the Uyghur American Association, www.uyghuramerican.org/researchanalysis/trans.html.

34. The meshrep are gatherings at the local level, favouring the communication of traditional Uyghur culture. This movement for revitalising traditional culture was intended also to stem the loss of "moral values" among young Uyghurs (the weakening of intergenerational solidarity, criminal behaviour, consumption of drugs and alcohol ...).

35. Amnesty International, "People's Republic of China: Gross Violations of Human Rights in the Xinjiang Autonomous Region", April 1st 1999, pp. 18-19.

36. On the rise of militant nationalism among young Uyghurs, see also the study by Joanne Smith, "Four Generations of Uyghurs: the Shift towards Ethno-political Ideologies among Xinjiang's Youth", Inner Asia, Vol. 2, No. 2, 2000, pp. 195-224.

37. Although this study sets out in particular to look at the political manifestations of the "Uyghur malaise" it is important to note that this malaise also feeds a "sub-political resistance" anchored mainly in the daily life of the Uyghurs. On this question, see Gardner Bovington, "The Not-So-Silent Majority: Uyghur Resistance to Han Rule in Xinjiang”, Modern China, Vol. 28, No. 1, January 2002, pp. 39-78.

38. This study is limited to active movements in Xinjiang. On political groupings in the Diaspora, see Frédérique-Jeanne Besson, "Les Ouïghours de la diaspora", Cahiers d'études sur la Méditerranée orientale et le monde turco-iranien (CEMOTI), n² 25, July-December 1998, pp. 161-192.

39. Cf note 6. On this point, over and above the debate about emancipation and the means to achieve it, the accent is placed either on the struggle for the recognition of the sovereign rights of the Uyghur nation, or else on the need to defend the interests of the various Turkic-speaking populations within the context of a Pan-Turkic project on the scale of Xinjiang: both views are aired in the debate among the different nationalist movements over how the region should be named: Uyghuristan in the former view, East Turkistan for the latter. See, on the question, ETIC, "Sherqiy Turkistanmu? Uyghuristanmu?" (East Turkistan? Uyghuristan?).

40. Interviews, Uyghur Diaspora 2002. According to Artoush Kumul, it was already active in the late 1950s (see Artoush Kumul, op. cit., p. 85).

41. Taipei Times, October 11th 1999.

42. Zhang Yumo, op. cit.

43. Ibid.

44. Cf note 8 .

45. Ibid.

46. The main part of the Uyghur Diaspora has sought refuge in Central Asia where it numbers according to the 1989 census in Kazakhstan 180,000 people (500,000 according to Uyghur associations), 40,000 people in Kirghizstan (250,000 according to the associations), 5,000 in Turkmenistan (20,000 for the associations) and a total that is hard to calculate in Uzbekistan (many Uyghurs having registered themselves as Uzbeks). The rest of the Diaspora is settled in Turkey (about 10,000 people) and, in smaller numbers, in Germany, Australia, Saudi Arabia, Sweden, Canada, the US, India and Pakistan.

47. The new name for the former Shanghai Group created in 1996, the SCO includes Russia, China, Kazakhstan, Kirghizstan, Tadjikistan and Uzbekistan.

48. Thus, for example, the government of Kazakhstan, which had officially recognised organisations seeking independence that were operating within its territory (The 
United National Revolutionary Front of East Turkistan, the Organisation for the Liberation of Uyghuristan and the Union of Uyghur Peoples) ended up by banning them in 1995 under pressure from the Chinese government. On the repression of the Uyghur militants in Central Asia, see ETIC, "Sherqiy Turkistanning 2002-yili YanwardinMayghiçe Bolghan Arliqtiki Insan Heqliri Weziyiti Heqqide Teyarlanghan Mehsus Dokilat" (Special report on the state of human rights in East Turkistan over the period January-May 2002), May 1st 2002, pp. 7-8.

49. Control over illegal religious activities was tightened by means of regulations such as Temporary Regulations on Controlling Religious Meetings in the Xinjiang Uyghur Autonomous Region in 1988 and Regulations on Religious Activities in the Xinjiang Uyghur Autonomous Region in 1995.

50. This list, commonly called Secret Document No. 7, stresses, for example, the need to purge the Communist Party and the local administration of their least reliable elements, to strengthen propaganda against separatism, to tighten control over the people of Xinjiang, to encourage the influx of officials and Han colonists within the Xinjiang Construction and Production Corps in order to control the region, to control strictly the building of new mosques, to give leading positions in the mosques and religious organisations to people who love their "mother country", to register all people who have been trained in religious schools without permission and to keep them under surveillance, to take "strong measures to prevent religion from interfering in social and political affairs..." See "Guanyu weihu Xinjiang wending de huiyi jiyao, zhongyang zhengzhiju weiyuanhui", op. cit.

51. In Xinjiang, the everyday use of torture, ill-treatment and executions following summary trials contrast with the relative mildness of the repressive apparatus in the interior of China itself. According to a report by Amnesty International, between April 1997 and 1999, a minimum of 190 executions were recorded (Amnesty International, "People's Republic of China": Gross Violations of Human Rights in the Xinjiang Autonomous Region", op. cit.). For Marie Holzman, the proportion of Uyghurs among Chinese citizens condemned to death is ten times higher than their share of the Chinese population (a personal communication). This repressive downturn was itself exacerbated by the serious events that took place in February 1997. On February 5th and 6th that year, violent rioting broke out in Ghulja (Yining). It was brutally put down. The police crackdown and the widespread arrests that followed instilled a climate of terror that left its mark on people's minds. Despite an official figure of nine killed and a hundred wounded, the probable death toll among the rioters reached several dozen. 52. Many books suspected of spreading "unhealthy" ideas are thus removed from the shelves and even publicly burned on occasion (the best-known case is that of Turghun Almas's books on the history of the Uyghurs). Uyghurs working in the administration as well as those who are students are strongly advised not to practise Islam on pain of disciplinary measures against them or even being thrown out of their universities or losing their jobs. The closure of mosques or illegal religious schools are routinely mentioned in the press, and the imams and preachers involved suffer heavy penalties. In March 2001, the Chinese regime launched a much disliked campaign called "the patriotic re-education of imams". The imams are thus obliged to attend patriotic education classes (at the risk of losing their authorization to practise) while numerous restrictions have been imposed on religious education in the region (for example, in the rest of China, the imams are fairly free to give religious instruction to an indefinite 
number of students in schools attached to the mosques; but in Xinjiang, they may not give instruction to more than one or two pupils each).

53. See, for example, ETIC, "Hitay Hokumiti Sherqiy Turkistanda Yurguziwatqan Bir Birige Zir Diniy Siyasetliri Arqiliq Ozining Asasi Qanunini Ayaq - Asti Qilmaqta" (The Chinese government violates its own constitution in the contradictory religious campaigns that it wages in East Turkistan).

54. For example, the events at Khotan in July 1995 are connected to the successive arrests of several charismatic imams. The uprising in Ghulja in February 1997 seems to have followed several unpopular measures among which was the banning of the meshrep and the arrest of a prayer group during Ramadan.

55. On the disturbances that have rocked Xinjiang over the last two years, Michael Dillon, "Xinjiang: Ethnicity, Separatism, and Control in Chinese Central Asia", Durham East Asian Papers, No. 1, 1995, pp. 17-31.

56. A score of Uyghur organisations have taken a step towards coordinating their activities by creating the East Turkistan National Congress (ETNC) and its permanent office in Munich in October 1999. The statutes and aims of the ETNC may be consulted on the web site: www.eastturkistan.com

57. Chinese military infrastructure, the railway lines that bring the Han colonists into Xinjiang and the pipelines that export local hydrocarbons to the rest of China are favoured targets for these acts of sabotage.

58. For an exhaustive list of the violent acts attributed by the Chinese regime to the separatists in Xinjiang, see “True nature of 'East Turkestan' forces”, China Daily, January 22nd 2002.

59. Ibid.

60. Ibid.

61. For many Uyghur militants, the absence of support from the West and particularly from the United States tends to drive some of them into the arms of the Islamists (Interviews, 1999-2002).

62. Coming mainly from Pakistan.

63. Bearing in mind the friendly relations that China and Pakistan strive to maintain, the subject is still taboo; but the comings and goings of Pakistani preachers following the opening of the Karakorum road to cross-border trade have seriously irritated the Chinese authorities. As a sign of protest, China closed its frontier with Pakistan between 1992 and 1994. A few months after it was reopened, China arrested nearly 450 Pakistanis who had committed "illegal actions" in Xinjiang. The Chinese diplomats refused to confirm that some of them had been arrested for religious or political proselytising but this silence seems to suggest this was the case (Nawai Waqt, June 4th 1996). Several Pakistani traders who regularly pass through Kashgar have indicated to me that they have stopped attending the mosque to "keep out of trouble with the Chinese authorities".

64. Stéphane Dudoignon, "Islam d'Europe? Islam d'Asie? En Eurasie centrale (Russie, Caucase, Asie centrale" in L'Islam en Asie, du Caucase à la Chine, edited by Andrée Feillard, Paris, La Documentation française, p. 67.

65. The HT is a neo-fundamentalist organization. Unlike the Jihadist parties whose primary aim is to seize political power by force, this organization focuses its action on the re-Islamization of Muslim people before concentrating on taking power by force. Originating in Jordan, it has spread across the Muslim world and particularly in Uzbekistan where it has become, together with the Islamic Movement of Uzbekistan, 
the bête noire of President Karimov. See Ahmed Rashid, Asie centrale, champ de guerres. Cinq Républiques face à l'islam radical, Autrement Frontières, Paris, 2002, pp. 106-123. This organisation has been operating for a while in Xinjiang. A few Uyghurs recruited in Uzbekistan and in Kirghizstan went back to Xinjiang to form cells that have spread in the late 1990s (Interviews, 2002).

66. International Herald Tribune, October 15th 2001.

67. In December 1995, about a hundred Uyghurs, mostly financed by the Jamaat-e Islami, took a course at the Sayed Mawdudi Institute at Lahore or in other Koranic schools in Pakistan (The Herald, December 1995).

68. In 1997, this neo-fundamendalist organisation declared that it was carrying out "missionary activities" on the other side of the Chinese frontier (Asia Times, February 12th 1997).

69. This guerrilla movement active in Kashmir is linked to the Jamaat-e Islami and to the Afghan Hizb-e Islami.

70. Influenced by Salafism, these movements "demand a return to strict Islam, free of any local customs or cultures" and "call for Jihad to recover 'occupied' Muslim lands, and even to fight against Muslim regimes that they consider as traitors" (Mariam Abou Zahab \& Olivier Roy, Réseaux islamiques. La connexion afghano-pakistanaise, collection CERI/Autrement, Paris, 2002, p. 5).

71. On these organisations, see Mariam Abou Zahab \& Olivier Roy, op. cit.

72. According to Indian officials, three Uyghurs were captured during battles in Kashmir two years ago.

73. "Jiangdu yu qian ren ladan ying shouxun" (More than a thousand independence campaigners from Xinjiang were given training in bin Laden's camps), Mingbao, November 3rd 2001.

74. Interviews, 2002.

75. The Uyghurs continue to practice a form of Islam that is still strongly influenced by Sufism and the cult of saints. Apart from those who have gone abroad or from some young urbans (who are often disconnected from Sufi networks), the people of Xinjiang are still generally resistant to the radical versions of Islam and often show themselves to be very critical of such practices.

76. The present rise to power of the HT in Xinjiang probably arises from its political methods, which are peaceful (which gives it a more "respectable" image) and ultrasecret (its militants are less exposed to Chinese repression than they would be by the violent acts of Jihadist groups.). It also accepts putting stress on the improvement of the individual and achieving well-being in the light of a purified form of Islam. Indeed, in addition to its political project of joining a great caliphate (and thus its aim of winning freedom from the Chinese "yoke"), the accent it puts on the individual religious dimension is considered by its adherents (often young urban dropouts) as the means of ending the social problems which affect Uyghur society (the collapse of social solidarity, criminality, drug-taking ...)

77. Zhongguo xinwenshe, July 7th 2000; South China Morning Post, "Victory claimed against Muslims Rebels", January 13th 2001.

78. See "Uygurs 'part of world problem"', South China Morning Post, November 16th 2001, “Bin Laden's Network: A Chinese View”, People's Daily, November 16th 2001;

"Guowuyuan: Ladan chuci peixun xindu)" (State Council: bin Laden finances the training of Xinjiang's independence activists)", Mingpao, January 22nd 2002 ,China Daily, January 22nd 2002 (op. cit.) 
79. Dongtu corresponds to the abbreviated form in Chinese of East Turkistan.

80. See China Daily, op. cit. The report published by the State Council accuses the ETIM of having set up cells in Xinjiang for training people how to handle explosives and for having created significant caches of arms and bomb-making products.

81. The fact that these organisations have very similar names, added to the presence of Uyghurs among the IMU fighters taken prisoner in northern Afghanistan, support this idea.

82. In fact, the American decision probably had less to do with the struggle against international terrorism than with American anxieties about China's exports of technologies considered to be "sensitive". For many analysts, adding the ETIM to this notorious black list had the principal aim of satisfying China so as to induce Peking to stop its missile sales to potentially aggressive countries (at the same time, China has indeed drawn up new regulations governing its missile exports) (Xinhua, August 26th 2002). 